\title{
PERAN STRATEGIS BAHASA INDONESIA DALAM PEMBENTUKAN NILAI KARAKTER ANAK
}

\author{
THE STRATEGIC ROLE OF BAHASA INDONESIA IN BUILDING \\ CHILDREN CHARACTER VALUES
}

\author{
Masayu Gay \\ Sekolah Tinggi Keguruan dan Ilmu Pendidikan, Kie Raha Ternate \\ Jalan STKIP, Jambula-Sasa, Kota Ternate Selatan \\ Tlp./Faks. (0921) 3120022 \\ Posel: Masayufm@yahoo.co.id
}

\begin{abstract}
Abstrak
Makalah ini bertujuan mendeskripsikan peran bahasa dalam pembentukan nilai karakter anak. Pendekatakan pustaka digunakan untuk mengulas konsep karakter menurut Munir yang menekankan pada pikiran, sikap, perkataan dan perbuatan, serta konsep karakter menurut Widjono mengenai hubungan antara bahasa dan karakter. Dalam makalah ini disimpulkan bahwa Bahasa Indonesia bukan hanya sekadar alat berkomunikasi, tetapi juga sebagai sarana yang dapat memengaruhi cara berpikir pemakainya, yang pada akhirnya menunjukkan karakter pemakainya. Nilai karakter tersebut tercermin pada ujaran yang digunakannya sehari-hari. Dengan demikian bahasa berperan penting dalam pembentukan nilai karakter tersebut melalui komunikasi. Pola komunikasi positif berdampak pada terbentuknya nilai karakter positif. Anak adalah individu yang labil, sehingga sangat rentan tumbuh dan berkembang sesuai lingkungan berbahasa di tempat ia berada. Komunikasi yang diterima atau didengar melalui pihak yang dianggap memiliki otoritas, seperti orang tua, guru, atau teman yang dipercayai akan diterimanya sebagai informasi yang benar.
\end{abstract}

Kata Kunci: Peran Bahasa Indonesia, Nilai Karakter, Anak

\begin{abstract}
This papers aims to describe the role of language in shaping the character values of children. Libraries research is used to review Munir's concept of the character which emphasis on the thoughts, attitudes, words and deeds, as well as Widjono's concept of character which studies the relationship between language and character. This paper concludes that Indonesian language is not just a means of communication, but it can also become a means which influence the way of thinking of its speakers, which in turns reflects the character of its speakers. The character values are reflected on the utterances in daily speaking. This means that language takes an important role in building the character of its speakers through communication. The pattern of positive communication impacts on the formation of a positive character values. Children are unstable individuals. They are prone to grow and develop unstable due to their surroundings. The patterns of communications received through authority parties such as the parents, teachers, or friends will be received as the correct information which will shape their characters.
\end{abstract}

Keywords: Indonesian language role, character values, children

\section{Pendahuluan}

Bahasa ibarat makanan yang diberikan dan siap disajikan oleh siapa saja. Makanan yang bergizi dan berlezat akan sangat baik bagi pertumbuhan bahkan kesehatan individu, begitu pun sebaliknya setiap individu akan tumbuh dengan 
kesehatan yang kurang baik jika sering mengonsumsi makanan tidak bergizi dan berlezat. Ilustrasi ini jika dihubungkan dengan bahasa, maka antara individu dan bahasa memiliki hubungan erat. Bahasa dijadikan sarana komunikasi bagi setiap individu dalam lingkungan berbahasa. Oleh karena itu, jika komunikasi melalui kata-kata imperatif halus atau eufemisme akan diterima dan ditafsirkan oleh individu lain sebagai sesuatu yang dapat menyejukkan hatinya.

Anak adalah individu yang dalam kesehariannya menerima dan mendengar ucapan-ucapan dari orang-orang di sekelilingnya, baik orang tua maupun teman. Proses mendengar dan menerima bahasa oleh anak akan berdampak padapembentukannilai karakter anak tersebut. Hal ini dikarenakan, bahasa merupakan sarana pembentukan karakter (pribadi) seseorang, sehingga karakter dan bahasa memiliki hubungan yang sangat erat.

Sejauh ini, kita mengalami degradasi moral yang sangat memprihatinkan yang dipicu juga oleh ketidaksantunan menggunakan bahasa. Interaksi melalui komunikasi, sering terdapat kata-kata makian. Kata-kata yang dapat memicu pembentukan nilai karakter negatif pada anak. Berbagai tindakan antisipasi pun dilakukan untuk meminimalisasi persoalan karakter bangsa saat ini. Salah satunya melalui pendidikan dengan konsep baru, yakni pendidikan berbasis karakter. Harapan pembentukan nilai-nilai karakter positif oleh pemerintah dipercayakan melalui proses pendidikan dan pembelajaran dengan sistem kurikulum yang terus diperbaharui (terakhir kurikulum 2013).

Lalu, bagaimana dengan bahasa sebagai sarana komunikasi kaitannya dengan pembentukan karakter anak, apakah bahasa berperan dalam pembentukan karakter anak? Jawabannya 'iya', sebab bahasa memiliki peran vital dalam kehidupan manusia. Bahasa berfungsi sebagai sarana komunikasi efektif dibandingkan sarana yang lain sehingga tanpa bahasa kehidupan akan lumpuh. Melalui bahasa manusia mengekspresikan diri, mengatakan perasaan, memerintah, mengatakan ide dan gagasan, menasihati, dan pengontrol sosial dengan kata-kata santun, sopan, halus (eufemisme) dan sebagainya.

Peran dan fungsi bahasa dalam kehidupan keluarga dan masyarakat terkadang salah digunakan. Bahasa belum maksimal diarahkan untuk pembentukan karakter pada anak. Tanpa sadar orang tua atau sejawat terkadang melontarkan kritik, makian (tabu) yang merugikan perkembangan psikis anak.

Menurut Hurlock (1978:23), semakin penting orang yang mengkritik bagi anak, semakin besar pengaruh kritik tersebut terhadap anak. Orang berubah menjadi baik atau buruk, karena bertambahnya pengalaman. Dengan disimpannya kejadian dalam organisme, individu tanpa kecuali mengambil dari bekasbekas pengalaman itu dan menciptakan kategori yang lebih rumit dan luas untuk menafsirkan peristiwa baru.

Penjelasan di atas menyiratkan bahwa pengalaman yang diperoleh anak akan mencerminkan tindakannya yang sesuai dengan apa pengalaman yang membentuknya. Anak yang semasa perkembangan dan pertumbuhannya selalu disuguhi kata-kata makian (tabu), misalnya: kata-kata kasar, cemooh, hinaan, dan sebagainyamelalui orang tua, sejawatakan berdampak negatif pada perkembangan nilai karakternya. Oleh karena, semua induksi dan afirmasi lewat komunikasi akan membentuk pengalaman anak tersebut. Dapat pula dimaksudkan bahwa jika pola komunikasi melalui bahasa positif akan terbentuk karakter yang positif pula.

Anak akan tumbuh dan berkembang dengan nilai karakter baik jika terdidik dalam lingkungan (keluarga atau masyarakat) yang pola komunikasi positif, penuh kelembutan, dan kasih sayang. Anak akan memperlakukan anak yang lain dengan penuh kelembutan dan kasih sayang pula. Sebaliknya, jika anak yang terdidik pada lingkungan yang tidak dengan pola komunikasi bahasa yang lembut dan santun maka anak akan tumbuh dan berkembang menjadi angkuh, egois, tidak bertanggungjawab, dan bahkan tidak memperlakukan anak lain dengan baik pula. Berbagai bentuk tindakan verbal pun akan mencerminkan nilai karakter anak. Oleh karena itu, sudah seharusnya bahasa diperkuat 
perannyasebagai sarana pengembangan karakter anak ke arah positif di era globalsaat ini.

Artikel ini membahas masalah pentingnya bahasa dalam pembentukkan nilai-nilai karakter pada anak. Bertujuan memberikan pengetahuan mengenai: (1) konsep nilai dan karakter; (2) fungsi dan peran bahasa; (3) menciptakan lingkungan bahasa yang mendukung perkembangan nilai karakter anak; dan (4) membentuk nilai karakter anak melalui Bahasa.

\section{Pembahasan}

\subsection{Nilai Karakter}

Karakter menurut Munir (2010:2) merupakan nilai-nilai perilaku manusia yang berhubungan dengan Tuhan Yang Maha Esa, diri sendiri, sesama manusia, lingkungan, dan kebangsaan yang terwujud dalam pikiran, sikap, perkataan, dan perbuatan berdasarkan norma-norma agama, hukum, tata krama, budaya, dan adat istiadat. Menurut Lickona (dalam Wiarto $d k k$, 2010:14), karakter terdiri atas tiga unjuk perilaku yang saling berkaitan, yaitu tahu arti kebaikan, mau berbuat baik, dan nyata berperilaku baik. Jadi, nilai karakter dapat diartikan sebagai pikiran, perkataan, dan perbuatan yang berdasarkan pada norma.

Menurut Bariqoh (2015:260), nilai akan selalu muncul ketika individu mengadakan hubungan sosial dengan masyarakat atau dengan individu lainnya. Nilai berasal dari bahasa Inggris yaitu value atau harga. Sesuatu itu, mempunyai nilai karena ia mempunyai harga, atau sesuatu itu mempunyai harga karena ia mempunyai nilai. Nilai yang dimaksud dalam hal ini adalah proses menimbang atau menaksir, yaitu kegiatan manusia yang menghubungkan sesuatu dengan sesuatu untuk selanjutnya diambil keputusan.

Nilai karakter menjadi modal yang kuat membangun kemajuan dan kedamaian bangsa. Juliandan Alfred ( 2008:115), salah satu harta yang paling berharga dalam kehidupan manusia adalah karakter. Bentuk karakter manusia di antaranya: kejujuran, kebaikan hati, ketenangan, kesetiaan, industri (bekerja keras), integritas, dan sejenisnya.

Berdasarkan beberapa pendapat di atas, disimpulkan bahwa nilai karakter adalah sekumpulan tatanilai yang berharga, dilandaskan pemikiran, sikap, yang muncul karena adanya hubungan sosial dengan masyarakat dan dengan individu lainnya. Karakter adalah semua bentuk nilai-nilai prilaku yang positif/prilaku baik oleh manusia dalam kehidupan bermasyarakat.Sedangkan, nilai karakter adalah cara berpikir dan berprilaku yang menjadi ciri khas tiap individu untuk hidup dan bekerja sama baik dalam lingkungan keluarga, masyarakat, serta bangsa dan negara. Nilai-nilai karakter tersebut muncul akibat adanya interaksi antara individu dengan sosial atau individu dengan individu lainnya. Jadi, orang yang berkarakter adalah yang memiliki kualitas moral positif. Dijadikan pegangan/petunjuk dalam melakukan berbagai tindakan verbal maupun nonverbal.

\subsection{Fungsi dan Peran Bahasa}

Bahasa adalah satu kemampuan yang dianugerahkan pada umat manusia. Sedemikian alamiahnya sehingga kita tak menyadari bahwa tanpa bahasa, umat manusia tak mungkin mempunyai peradaban yang di dalamnya termasuk agama, ilmu pengetahuan, teknologi (Corballis, 2011, Vossler, Yu, 2013). Bahasa merupakan salah satu properti yang lekat secara biologis pada manusia dan hampir semua aktivitas manusia memerlukan bahasa (Bickerton, 1992, Jenkins, 2000, Smit, 2014). Dengan demikian, tidaklah berlebihan jika kita mengatakan bahwa kajian mengenai bahasa sangat bermanfaat karena membantu memahami dan menata kehidupan manusia di berbagai bidang (Jackson dan Stockwell, 2011, Wardhaugh dan Fuller, 2015).

Fungsi dan peran bahasa (bahasa Indonesia, daerah, dan melayu/perantara) samasama penting. Ketiga bahasa tersebut digunakan dalam kehidupan sehari-hari sebagai sarana komunikasi sesuai konteksnya. Sejauh ini peran dan fungsi ketiga bahasa tersebut sudah sangat baik, terutama bahasa Indonesia. Namun demikian, tidak dapat dinafikkan kalau peran dan fungsinya terkadang salah digunakan bukan sebagai sarana pengembangan karakter. Katakata yang mengandung makna halus dan penuh kelembutan (eufemisme) digantikan dengan kata-kata keji, kotor, kata-kata yang mengkerdilkan pendengar, mengutuk (kata makian) dalam komunikasi sehari-hari, baik di rumah, kantor, tempat-tempat umum, maupun di sekolah. Penggunaan kata-kata makian tentu 
sangat merugikan anak dalam tahapan perkembangan karakternya.

\subsection{Membentuk Nilai Karakter Anak melalui Bahasa}

Anak dalam melakukan interaksi semua indranya siap merespon semua hal yang ia rasa, lihat, cium, dan dengar. Nah, indra pendengar adalah salah satu indra yang sangat aktif mendengarkan berbagai macam bunyi, terutama bunyi-bunyibahasa yang diucapkan orang atau melalui media audio visual, dan media hidup lain. Bunyi-bunyi bahasa yang didengarkanmelaluiinteraksi secara langsung maupun tidak langsung oleh anak melalui orang tua, guru, dan sejawat akan menjadi induksi untuk membentukkarakternya. Karena itu, dalam berkomunikasi diutamakan ungkapanungkapan halus agar memunculkan kasih sayang, keramahan, kesenangan dan lain-lain. Selain itu, menghindari makian (tabu).

Menurut Webster New World Dictionary (Neufeldt dan Guralnilk, (ed.), 1994:1351) (dalam Suryatin, 2011:25), makian memiliki beberapa arti, yaitu (1) membuat pernyataan serius dengan memohon kepada Tuhan atau sesuatu yang dianggap suci untuk memberikan sumpah atas nama seseorang; (2) membuat janji yang serius; (3) mengutuk; (4) berdalil untuk memberikan bukti di bawah sumpah.

Makian merupakan perasaan tertentu yang timbulnya disebabkan oleh dorongan yang bersifat kebahasaan dan nonkebahasaan berupa kata-kata yang diucapkan oleh seseorang yang dirasa tidak berkenan pada diri pemaki. Sebagai tanggapan atas tindakan itu, si pemaki melampiaskan perasaannya melalui pelbagai makian. Sementara itu, hal yang bersifat nonkebahasaan biasanya menyangkut perbuatan seseorang atau peristiwa tertentu. Perbuatan tertentu misalnya pemukulan atau peristiwa tertentu seperti penyesalan mengakibatkan seseorang marah, jengkel, atau kecewa. Dalam suasana seperti itu, biasanya orang terbawa luapan perasaan yang menegangkan saraf. Pada saat itulah, perasaan sering terungkap melalui kata-kata yang tergolong kasar. Salah satu pengungkapan tersebut adalah dengan mencaci maki penyebabnya (Concon, 1996:95) (dalam Suryatin, 2011:25-26).

Moeliono (2003:702) menyatakan bahwa makian merupakan kata-kata keji yang diungkapkan karena marah. Bentuk tuturan makian dapat dikelompokkan atas kata, frasa, dan kalimat. Moeliono, dkk. (2003:36) menjelaskan bahwa ungkapan makian dalam kategori sintaksis dapat dibedakan menjadi empat, yakni (1) verba atau kata kerja, (2) nomina atau kata benda, (3) adjektiva atau kata sifat, dan (4) adverbial atau kata keterangan.

Fungsi ungkapan makian merupakan sebagai sarana mengungkapkan rasa marah, juga dapat digunakan sebagai sarana pengungkapan rasa kesal, rasa kecewa, penyesalan, keheranan penghinaan, dan sebagai sarana untuk memelihara keintiman atau suasana akrab dalam suatu pergaulan. Menurut Rothwell (1973:7) (dalam Refmianti, dkk., 2012:382) terdapat beberapa tujuan utama dari penggunaan kata makian. (1) mencari perhatian; artinya, orang yang menggunakan kata tabu atau makian menginginkan dirinya menjadi pusat perhatian dari lingkungan sekitar. (2) mendiskreditkan; orang yang menggunakan kata tabu tidak puas dengan citra orang tertentu, lembaga, atau pemerintahan, dan lain-lain. (3) menghasut; kata makian tertentu dapat membawa korban apabila pendengarnya merasa terhina dan dilecehkan. (4) mengidentifikasi; artinya, makian dapat difungsikan untuk membentuk identifikasi personal yang kuat. (5) sebagai katarsis; ketika seseorang marah atau terganggu atau tersakiti secara fisik dan mental, dia akan menunjukkan perasaannya.

Penggunaan bahasa-bahasa makian merupakan cermin karakter seseorang. Pranowo (2009:3), bahwa bahasa merupakan cermin kepribadian seseorang. Lebih jauh dapat dikatakan bahwa bahasa merupakan cermin kepribadian bangsa. Artinya melalui bahasa yang digunakan seseorang atau suatu bangsa dapat diketahui kepribadiannya. Kita akan sulit mengukur apakah seseorang memiliki kepribadian baik atau buruk jika mereka tidak mengungkapkan pikiran atau perasaannya melalui tindak bahasa (baik verbal maupun nonverbal). Hal ini mengisyaratkan bahwa bahasa berkaitan erat dengan kepribadian seseorang karena makna tuturan melalui kata merupakan cerminan pribadi pembicara sebagai bentuk karakternya.

Sudaryat (2009:66), menjelaskan kosakata atau leksikon sangat bermanfaat dalam 
kehidupan untuk meningkatkan taraf hidup, kemampuan mental, dan perkembangan konseptual pemakai bahasa, mempertajam proses berpikir kritis, dan memperluas cakrawala pandangan hidup pemakainya. Widjono (2012:20) menjelaskan salah satu fungsi bahasa adalah "bahasa membangun karakter". Menurutnya kecerdasan merupakan bagian dari karakter manusia. Kemampuan berbahasa yang efektif, logis, sistematis, lugas, jelas, dan mudah dipahami merupakan refleksi kecerdasan. Kecerdasan berbahasa memungkinkan seseorang dapat mengembangkan karakternya yang lebih baik.

Bahasa membentuk karakter disebabkan bahasa mengandung makna dan memiliki kekuatan. Kekuatan bahasa apabila dihubungkan dengan penelitian yang dilakukan oleh MassaruEmoto (2006) (dalam Pamungkas, 2012:20), bahwa energi positif yang terdapat dalam bahasa mampu membentuk kristal yang sangat indah (Baca: Pamungkas, 2012:20-21). Teori ini membuktikan bahwa bahasa memiliki kedahsyatan. Tata bahasa yang baik, diksi yang disesuaikan dengan konteks, ekspresi yang menyenangkan orang lain, gestureyang membuat orang lain tidak tersinggung, gaya bahasa yang santun, dan menyejukkan hati orang lain tentu akan memberikan energi positif yang luar biasa. Pamungkas (2012:24) menjelaskan bahwa dengan bahasa yang baik, tentu seseorang akan bertingkah laku yang baik pula.

Setiap orang dapat menghormati dan menyayangi orang lain melalui bahasa. Pranowo (2009:5), menjelaskan ketika seseorang menyampaikan maksud ingin meminta tolong pada orang lain, hendaknya maksud tersebut disampaikan dengan menggunakan bentuk santun (imperatif halus). Jika permintaan permintaan tolong itu ditujukan kepada orang yang dihormati, hendaknya digunakan kata-kata imperatif halus, seperti "mohon bantuannya", "sudilah kiranya", jika maksud ini ingin minta bantuan tersebutdisampaikan denganmenggunakan bahasa lisan, penutur hendaknya juga menyertai sikap-sikap yang sudah disepakati masyarakat sebagai sikap hormat (badan membungkuk, pandangan mata tidak melotot, volume suara tidak terlalu keras, dan sebagainya).
Penjelasan ini mengandung pengertian timbal balik. Maksudnya, saling menghargai, menerima, menyayangi, dan mencintai antara satu dengan yang lain merupakan karakter yang saling berkaitan. Jika seseorang memulai suatu tindakan verbal yang positif kepada orang lain, orang lain pun akan melakukan tindakan yang sama. Coba dibayangkan, seandainya bahasa telah memenuhi peran strategis sebagai media pembentukan nilai-nilai karakter apa yang akan terjadi? Tentu hubungan antarmanusia akan penuh dengan kebahagiaan dan kedamaian. Dinyatakan oleh Anwar (1995:38) bahwa penggunaan bahasa secara gegabah dapat merugikan masyarakat dan menurunkan tingkatan peradaban. Jadi, dapat menurunkan kualitas kehidupan. Selanjutnya, pemakaian bahasa secara jujur dan tepat cenderung mempertinggi budaya. Penggunaan bahasa seperti ini diistilahkan olehnya sebagai 'sofistikasi'.

\subsection{Menciptakan Lingkungan Bahasa yang Mendukung Perkembangan Nilai Karakter Anak}

Setiap anak terlahir dalam keadaan suci. Pembawaan (gen) merupakan salah satu potensi yang melekat pada setiap anak yang lahir. Namun, potensi akan tumbuh dan berkembang ditentukan pula oleh lingkungannya. Lingkungan merupakan salah satu komponen dalam pembentukan karakter seseorang, baik atau buruk. Setiap anak sebenarnya terlahir dengan potensi untuk menjadi anak yang memiliki karakter baik, tetapi tergantung lingkungan di mana anak hidup dan dibesarkan.

Almatin (2010:68), memaparkan bahwa karakter/sifat anak dapat dibentuk melalui halhal sebagai berikut.

Jika anak dibesarkan dengan celaan, ia akan belajar memaki.

Jika anak dibesarkan dengan permusuhan, ia belajar berkelahi.

Jika anak dibesarkan dengan ketakutan, ia belajar gelisah.

Jika anak dibesarkan dengan rasa iba, ia belajar menyesali diri.

Jika anak dibesarkan dengan olok-olok, ia belajar rendah diri.

Jika anak dibesarkan dengan iri hati, ia belajar kedengkian. 
Jika anak dibesarkan dipermalukan, ia belajar merasa bersalah.

Jika anak dibesarkan dengan dorongan, ia belajar percaya diri.

Jika anak dibesarkan dengan pujian, ia belajar menghargai.

Jika anak dibesarkan dengan penerimaan; ia belajar mencintai.

Jika anak dibesarkan dengan pengakuan, ia belajar mengenali tujuan.

Jika anak dibesarkan dengan rasa berbagi, ia belajar kedermawanan.

Jika anak dibesarkan dengan kejujuran dan keterbukaan, ia belajar kebenaran dan keadilan.

Jika anak dibesarkan dengan rasa aman, ia belajar menaruh kepercayaan berdamai dengan pikir.

Jika anak dibesarkan dengan rasa persahabatan, ia belajar menemukan cinta dalam kehidupan.

Jika anak dibesarkan dengan ketentraman, ia belajar berdamai dengan pikiran.

Berdasarkan enam belas poin di atas dapat dikatakan bahwa pola didikan termasuk melalui komunikasi dalam lingkungan (keluarga, sekolah, masyarakat) sangat berperan penting pada pembentukan nilai karakter anak. Oleh sebab itu, kita hendaknya menghindari pola komunikasi, pemberian sugesti, induksi, dan afirmasi yang negatif melalui bahasa.

Lingkungan dalam hal ini keluarga dan masyarakat merupakan tempat tumbuh dan berkembangnya anak. Namun, pertumbuhan dan perkembangan karakter anak menjadi subjektif, tergantung pengalaman di lingkungan tempat mereka tumbuh, hubungan mereka dengan sejawat atau orang-orang yang berarti bagi kehidupan mereka, bahkan bimbingan yang mereka terima dalam mengendalikan emosinya. Di sinilah permulaan karakter anak akan terbentuk. Oleh karena itu, jika lingkungannya baik, pembentukan karakter pun akan pula baiknya.

Sayangnya, sebagian besar anak tumbuh dalam lingkungan banyak memberikan pengalaman karakter tidak menyenangkan, antara lain anak sering disuguhi dengan katakata kasar dan makian baik dalam lingkungan keluarga, teman dekat, maupun lingkungan masyarakat. Anak tidak mendapat sentuhan lembut dan kasih sayang melalui bahasa-bahasa yang halus, lembut, dan menyenangkan. Anak tidak mendapat kesempatan untuk dinasihati dengan bahasa-bahasa lembut. Mereka tidak hanya terampas dalam hal pengalaman yang memuaskan ego karena dicintai dengan bahasa yang penuh kelembutan, sehingga anak merasa mendapat kasih sayang.Besarnya pengaruh emosi yang menyenangkan seperti kasih sayang, cinta, kegembiraan, dan kebahagiaan menyebabkan timbulnya perasaan aman yang akan membantu anak-anak dalam menghadapi masalah mereka dengan penuh kepercayaan pada diri sendiri dan ketenangan (Hurlock, 1978:229).

Berdasarkan penjelasan di atas dapat dikatakan bahwa manusia semenjak ia lahir dalam kesehariannya melakukan komunikasi dan menerima informasi maupun induksi dari lingkungan. Setiap informasi yang ia terima, baik dari orang tua maupun sejawat jika berhasil menembus pikiran bawah sadar akan menjadi database yang akan membentuk karakternya. Oleh sebab itu, jika komunikasi positif selalu didengar oleh anak di tempat ia tumbuh dan berkembang (keluarga dan masyarakat), yang juga dapat menembus pada alam bawah sadar akan membentuk fail/database anak tersebut.

Penciptaan lingkungan berbahasa yang baik sangatlah penting. Berkomunikasi dalam lingkungan harus penuh dengan kelembutan dan kasih sayang. Jika seorang ayah/ibu memanggil anaknya dengan bahasa yang lembut, maka anak akan berbahasa dengan lembut pula. Jika seorang kakak di rumah memanggil adiknya dengan kata yang penuh kasih sayang atau sebaliknya, maka sang adik/kakak merasa disayangi dan dihargai. Begitu pula di lingkungan sekolah dan masyarakat.

\section{Simpulan}

Berdasarkan pembahasan di atas, disimpulkan bahwa nilai karakter berupa perkataan mencerminkan sikap kesantunan, kejujuran, dan kasih sayang. Nilai karakter tersebut akan tumbuh pada diri seorang anak bergatung pada lingkungan bahasa. Kata-kata makian perlu dihindari pemakainnya. Pihak yang memiliki otoriter perlu mengutamakan bahasa yang halus, lembut, serta bermakna kasih sayang saat berkomunikasi dengan anak. Hal ini disebabkan 
anak akan menerima informasi melalui pihakpihak tersebut sebagai suatu kebenaran yang akan ia munculkan dalam sikap dan perkataannya. Dengan demikian, lingkungan berbahasa tempat anak berada harus mencerminkan pola komunikasi yang menyenangkan agar perkembangan emosi positif benar-benar terbentuk pada diri anak.

\section{Daftar Pustaka}

Almatin, I. 2010. Dahsyatnya Hipnosis Learning untuk Guru dan Orang Tua. Yogyakarta: Pustaka Widyatama.

Anwar, H. 1995. Beberapa Aspek SoisoKultural Masalah Bahasa. Yogyakarta: Gajah Mada University Press.

Bariqoh, A. 2015. Ekranasi Film Biopic: Penanaman Nilai Semboyan "Jas Merah" sebagai Usaha Pembentukan Karakter Mahasiswa STKIP PGRI Sampang. Prosiding Seminar International Riksa Bahasa IX. 26 November 2015, Bandung, Indonesia. Hal. 260.

Bickerton, Derek.1992. Language\&Species. Chicago: University of Chicago Press.

Budiningsi, Asri, C. 2005. Belajar dan Pembelajaran. Jakarta: PT Rinek Cipta.

Corballis, M. C. 2011. The RecursiveMind: The Origins of Human Language, Thought, andCivilization. Princeton, New Jersey: PrincetonUniversity Press.

Hurlock, B. E. 1987. Perkembangan Anak. Jakarta: Erlangga.

Jenkins, Lyle. 2000. Biolinguistics: ExploringtheBiology of Language. Cambridge: CambridgeUniversity Press.

Julian M., James dan John Alfred. 2008. Belajar Kepribadian. Yogyakarta: Penerbit BACA.

Moeliono, A. M. dkk. 2003. Kamus Besar Indonesia. Jakarta: Balai Pustaka.

Moeliono, A. M. 2003. Tata Bahasa Baku Bahasa Indonesia. Jakarta: Balai Pustaka.
Munir, A. 2010. "Pendidikan Karakter Membangun Karakter Anak Sejak dari Rumah". Yogyakarta: Pustaka Insan Madani.

Pamungkas, S. 2012. Bahasa Indonesia dalam Berbagai Perspektif. Yogyakarta: Andi.

Pranowo. 2009. Berbahasa Secara Santun. Yogyakarta: Pustaka Pelajar:

Refmianti, dkk. 2012. Ungkapan Makian Bahasa Minangkabau di KenagarianTaluk Kecamatan Lintou Buo Kabupaten Tanah Datar. Jurnal Pendidikan Bahasa dan Sastra Indonesia. Vol. 1 (1): 381.

Smit, Harry. 2014. The Social Evolution of Human Nature; From Biology to Language. Cambridge: Cambridge University Press.

Sudaryat, Y. 2009. Makna dalam Wacana. Bandung: Yrama Widya.

Suryatin, E. 2011. Bunga Rampai: Hasil Penelitian Kebahasaan. Kalimantan Selatan: Balai Bahasa Banjarmasin.

Vossler, Karl. 2014. The Spirit of Languagein Civilization. [1932]. Oxford and New York: Rautledge.

Wardhaugh, Ronald, and Fuller, Janet M. 2015. An Introductionto Sociolinguistics. Seventhedition. Malden, MA \& Oxford: Wiley-Blackwell.

Wiarto, Edi, D., dkk. 2010. Pendidikan Karakter: Kumpulan Pengalaman Inspiratif. : Jakarta: Kementerian Pendidikan Nasional Indonesia.

Widjono. 2012. Bahasa Indonesia: Mata Kuliah Pengembangan Kepribadian di Pergutuan Tinggi. Jakarta: PT Grasindo.

Yu, Xing. 2013. Languageand State: And InquiryintotheProgress of Civilization. Lanham, Maryland \& Plymouth, UK: University Press of America. 